\title{
The Spillover Effects of U.S. Monetary Policy Normalization on the BRICS Based on Panel VAR Model
}

\author{
Qi Deng (iD, Weiguo Xiao (iD, and Huan Yan \\ Economics and Management School, Wuhan University, Wuhan 430000, China \\ Correspondence should be addressed to Qi Deng; qideng@whu.edu.cn
}

Received 28 December 2021; Revised 7 January 2022; Accepted 10 January 2022; Published 27 January 2022

Academic Editor: Miaochao Chen

Copyright ( $) 2022$ Qi Deng et al. This is an open access article distributed under the Creative Commons Attribution License, which permits unrestricted use, distribution, and reproduction in any medium, provided the original work is properly cited.

\begin{abstract}
Using the monthly data from December 2008 to March 2018 and a panel vector autoregression (PVAR) model, this paper empirically analyzes the spillover effects of U.S. monetary policy normalization on the total output, inflation, trade balance, and exchange rates in BRICS. The results show that the Fed's interest rate hike and balance sheet shrinking will both lead to a decrease in BRICS' output, a decline in inflation, a deterioration in the trade balance, and a depreciation of the exchange rate. In addition, the spillover effects of the Fed's interest rate hike and shrinking of a balance sheet are both relatively long lasting, but there is a certain difference between the two effects; that is, the Fed's interest rate hike has a greater impact on the macroeconomic variables of BRICS countries than the shrinking of balance sheet. Based on the conclusions, we propose to establish and improve the regulatory system of international capital flows, pay close attention to commodity prices, and strengthen policy coordination and communication among BRICS countries so as to mitigate the adverse impact of U.S. monetary policy normalization.
\end{abstract}

\section{Introduction}

Since May 2013 to May 2018, the Federal Reserve has started the process of withdrawing quantitative easing measures and returning to the normalization of monetary policy. During this period, the international financial markets experienced severe turbulence, casting a shadow over the postcrisis recovery of the world economy. From the beginning of 2017, with the implementation of a series of fiscal, tax, and trade policies of the Trump administration, the U.S. economy began to recover strongly, the Fed gradually accelerated the pace of interest rate hikes, and the balance sheet normalization principles and plans were also mentioned on the agenda. Given that the U.S. is currently the world's largest economy, and the international monetary system is still dominated by the U.S. dollar, the adjustment of the U.S. monetary policy is bound to cause global economic and financial resonance. As representative emerging market economies, Brazil, Russia, India, China, and South Africa-the so-called BRICS—-may also be affected by the U.S. monetary policy, which is mainly reflected in the following aspects: first of all, the Fed's interest rate hike and balance sheet normalization lead to higher long-term yields by influencing the market's expectations of future short-term interest rates and term premiums rising long-term yields, while policy rates in economies such as Japan and Europe remain at the zero lower bound, and the widening of interest rate spreads triggers a reversal of international capital flows and increases the risk of financial volatility in other economies, which is not conducive to the actual economic development; secondly, the normalization of the U.S. monetary policy will withdraw a large amount of liquidity from the market and restrain international commodity prices, which may bring imported deflation to emerging economies, especially BRICS countries. Finally, under the dual effects of interest rate hikes and balance sheet shrinking, the U.S. dollar will continue to strengthen in the medium and long term, which may lead to the depreciation of the exchange rate of other economies against the U.S. dollar, increase the trade balance of other economies through the expenditureswitching effect, and thus benefit the real economic development of other economies.

Against this background, this paper aims to explore whether U.S. monetary policy normalization has significant 
spillover effects on output, inflation rate, trade balance, and exchange rate in BRICS countries. If so, what is the direction of this spillover effect? and how long will the effects last?; answering these questions will help to understand the impact of the U.S. monetary policy on the BRICS countries during the period of global monetary policy divergence; it will also help strengthen the coordination of monetary, trade, and exchange rate policies among the BRICS countries. The marginal contributions of this paper are twofold. First, to the best of our knowledge, different from the previous studies which only examined the spillover effect of the U.S. single monetary policy, this is the first attempt to examine both the spillover effect of the U.S. interest rate policy and the balance sheet policy on BRICS countries. Second, different from the previous studies which focused on the impact of the U.S. monetary policy on a single country, we use the PVAR model to study the impact of U.S. monetary policy normalization on BRICS countries within the same technical framework.

\section{Literature Review}

There is a large body of early literature analyzing the spillover effects of an unconventional monetary policy (see Papadamou et al. [1] for a review). As the U.S. monetary policy gradually returns to normalization, the relevant literature begins to emerge. The relevant literature on U.S. monetary policy normalization can be broadly divided into three categories:

The first stream of literature focuses on the impact of the Fed's interest rate hike on macroeconomic variables of other economies. Most of the literature studies have found that fed rate hikes have negative spillover effects on other economies. Sun and Zhang [2] used the TVP-VAR model to test the impact of the Fed's interest rate hike on China's output. The empirical results found that the impact of the Fed's interest rate hike on China's output was time varying, and the impact of the Fed's interest rate hike in 2015 on China's output was negative. By constructing a two country DSGE model, Banerjee et al. [3] empirically documented that a negative U.S. monetary policy shock leads to a retrenchment in EME capital flows, a fall in EME GDP, and a falling exchange rate, and found that financial friction exacerbated international spillovers. Georgiadis [4] used the GVAR model to study the determinants of the global spillover effects from the U.S. monetary policy and found that a U.S. contractionary monetary policy has a negative impact of output in most emerging economies, and the spillover effect on nonadvanced economies is usually less than advanced economies. Checo et al. [5] used the FAVAR model to estimate the impact of a U.S. monetary policy shock on Central America and the Dominican Republic economies, and empirical evidence shows that a positive federal funds rate shock pushes down real output, exports, and imports. Iacoviello and Navarro [6] argued that higher U.S. interest rates would have an impact on the prices of various financial assets held abroad, thus affecting foreign real economic activity; even after controlling exchange rates and trade channels, they found further evidence that a 100-basis-point rise in U.S. interest rates would reduce output in advanced economies and in emerging economies by $0.5 \%$ and $0.8 \%$, respectively. Aizenman et al. [7] argued that emerging economies with stronger economic fundamentals received more capital inflows during the quantitative easing phase and that capital flows would reverse during the withdrawal of quantitative easing, leading to sharp capital outflows and worsening financial conditions in emerging economies, and thus impacting the real economy. Tan et al. [8] used the event research method to empirically examine the impact of the withdrawal of quantitative easing on emerging economies, and the empirical results showed that the withdrawal of quantitative easing would lead to the reduction or even reversal of capital inflows in emerging economies, thus leading to exchange rate depreciation and a decline in the real economy. Almahadin [9] used the ARDL approach to investigate the impact of the U.S. monetary policy on the banking development of five Asian countries, and they found that the U.S. monetary policy has a negative spillover effect on banking development. Anaraki [10] used a fixed effect model to find that the Fed's interest rate policy plays a dominant role in explaining capital reversal for BRICS countries.

There is also a subset of literature that Fed rate hikes have a positive spillover effect on other economies. Using the dynamic factor model, Hanisch [11] found that a contractionary U.S. monetary policy leads to the increase of real economy and inflation rate in Euro-zone member countries. The main reason is that the devaluation of the Euro against the U.S. dollar would improve the Euro area's trade balance and trigger economic growth. Zhou [12] used the GVAR model to study the impact of the Fed's interest rate hike on the world economy and found that the Fed's interest rate hike would improve the output of other countries in the world through trade channels. The analysis held that the appreciation of the U.S. dollar brought by the interest rate hike would reduce the cost of overseas investment with the U.S. dollar, thus increasing global FDI. In addition, the Fed's rate hike sent a signal to the market that the U.S. economy is recovering, thus promoting the recovery of global trade and increasing the real output of the global economy.

The second stream of literature focuses on the impact of the Fed's shrinking balance sheet on macroeconomic variables in other economies. Bai et al. [13] argued that a reduction in the Fed's balance sheet would signal a fall in output to the Chinese private sector, which will lead to a decrease in investment activities, thus affecting China's actual economic growth. Jiang et al. [14] argued that the shrinking of the balance sheet will affect the long-term yields of U.S. treasury bonds, while significantly reducing market liquidity. The strength of the U.S. dollar will increase the pressure on capital outflows from emerging market economies that would have a negative impact on emerging economies. Apostolou and Beirne [15] used a two-step method to analyze the volatility spillover of the Federal Reserve balance sheet to macroeconomic and financial variables in emerging market economies and found that the change in the Federal Reserve balance sheet can explain the volatility of stock yields, bond spreads, and bilateral 
exchange rates in almost all emerging market economies but have very limited spillover effects on volatility in the real economy, and there is no evidence that changes in the Fed's balance sheet have an impact on inflation volatility in emerging market economies.

The third stream of literature focuses on the impact of the Fed's interest rate hike and balance sheet reductions on macroeconomic variables in other economies. Brainard [16] argued that the Federal Reserve's interest rate policy and balance sheet policy mainly affect long-term bond term premium and money market interest rate, respectively. As the exchange rate is more sensitive to changes in short-term interest rates, the interest rate policy has a stronger spillover effect on net export and output of other economies compared with the balance sheet policy. Singh et al. [17] built a simplified twocountry model that included developed and emerging economies and found that the adjustment of short-term interest rates in developed economies would reduce their bond prices. For emerging economies with a fixed exchange rate system, the asset prices of emerging economies would change with the bond prices of developed economies. Shrinking balance sheets in advanced economies not only changes the price of domestic bonds but also affects the supply of domestic bonds; as a result, the changes of asset prices in emerging economies are not synchronized with those in developed economies, and the initial price decline is relatively slow. Song and Ye [18] argued that the Fed's interest rate hike and balance sheet reduction will lead to liquidity tightening in the U.S. market and capital outflow in China, and the U.S. dollar will continue to strengthen in the medium and long term, which will have an impact on China's economy. Xiao and Lan [19] empirically tested the spillover effect of the U.S. monetary policy normalization on China's economy by using a TVP-VAR model and empirically found that the Fed's interest rate hike would raise China's price level in the short term, resulting in an overall decline in China's output. But shrinking the Fed's balance sheet would generally lead to lower inflation and higher output in China.

According to the research conclusions of existing literature, it can be found that there is still controversy over whether the Fed's interest rate hike will reduce the output of other economies. There are a few literature studies about the cross-border spillover of balance sheet shrinking and most of literature studies are mainly theoretical analysis, which need further empirical tests. Based on the existing literature, this paper takes BRICS countries as the research object, uses the PVAR model to empirically test the spillover effects of the Fed's interest rate hike and balance sheet reduction on BRICS' output, inflation rate, trade balance, and exchange rate, and finally puts forward feasible policy suggestions based on the research conclusions.

\section{Model Setting, Variable Selection, And Data Description}

In this paper, we use the panel vector autoregression (PVAR) model to test the spillover effect of the U.S. monetary policy normalization on BRICS countries. The PVAR model combines traditional VAR models with panel data, first proposed by Holtz-Eakin et al. [20] and later developed by Arellano and Bond $[21,22]$. It has been widely used in many fields. Like the traditional VAR model, the PVAR model treats all variables in the system as endogenous variables. At the same time, it has the advantages of panel data analysis, which can control the unobserved individual heterogeneity. Therefore, the PVAR model can more objectively and accurately reflect the relationship among economic variables.

3.1. Model Setting. We set a PVAR model with six variables, as shown below:

$$
Y_{i, t}=\Gamma_{0}+\Gamma(L) Y_{i, t-p}+\mu_{i}+e_{i, t},
$$

where $Y_{i, t}=\left(\mathrm{IR}_{t}\right.$, Fedasset $\left._{t}, \mathrm{GDP}_{i, t}, \mathrm{CPI}_{i, t}, \mathrm{BOT}_{i, t}, \mathrm{REER}_{i, t}\right)$ are $M \times 1$ dimension vectors, $i$ represents the sample country, $t$ represents the month, $p$ represents the lag order, $\Gamma_{0}$ represents the constant term vector, $\Gamma(L)=\Gamma_{1} L^{1}+\Gamma_{2} L^{2}+$ $\ldots+\Gamma_{p} L^{p}$ represents the parameter matrix of the delay operator, $\mu_{i}$ represents the individual fixed effect, and $e_{i, t}$ represents the error term vector. Because individual fixed effect is related to the lag term, the traditional mean difference can lead to parameter estimation bias. To avoid estimation bias, forward mean difference, or Helmert procedure, is used in this paper to eliminate individual fixed effects.

Let $\bar{y}_{i, t}^{m}=\sum_{s=t+1}^{T_{i}} y_{i, s}^{m} /\left(T_{i}-t\right)$ represent the means obtained from the future values of $y_{i, s}^{m}$, which is a variable in the vector $Y_{i, t}=\left(y_{i, t}^{1}, y_{i, t}^{2}, \ldots, y_{i, t}^{M}\right)^{\prime}$, where $T_{i}$ represents the last period of data sample. Similarly, let $\bar{e}_{i, t}^{m}=\sum_{s=t+1}^{T_{i}} e_{i, s}^{m} /\left(T_{i}-t\right)$ represent the means obtained from the future values of $e_{i, s}^{m}$, which is a variable in the vector $e_{i, t}=\left(e_{i, t}^{1}, e_{i, t}^{2}, \ldots, e_{i, t}^{M}\right)^{\prime}$. Then, we can get the following transformed variable:

$$
\begin{aligned}
& \tilde{y}_{i, t}^{m}=\delta_{i, t}\left(y_{i, t}^{m}-\bar{y}_{i, t}^{m}\right), \\
& \tilde{e}_{i, t}^{m}=\delta_{i, t}\left(e_{i, t}^{m}-\bar{e}_{i, t}^{m}\right),
\end{aligned}
$$

where $\delta_{i, t}=\sqrt{\left(T_{i}-t\right) /\left(T_{i}-t+1\right)}$. Since there is no future value for constructing the forward mean, we cannot use the above method to calculate the transformation value for the last period of data. Thus, the final transformed model is given by

$$
\widetilde{Y}_{i, t}=\Gamma(L) \tilde{Y}_{i, t}+\widetilde{e}_{i, t},
$$

where $\tilde{Y}_{i, t}=\left(\tilde{y}_{i t}^{1}, \tilde{y}_{i t}^{2}, \ldots, \widetilde{y}_{i t}^{M}\right)^{\prime}$, and $\tilde{e}_{i t}=\left(\widetilde{e}_{i t}^{1}, \widetilde{e}_{i t}^{2}, \ldots, \widetilde{e}_{i t}^{M}\right)^{\prime}$.

3.2. Variable Selection and Data Description. The sample period of this paper is from December 2008 to March 2018, considering the availability of some data. The sample period covers the whole period of the unconventional monetary policy and the period of monetary policy normalization. Variable selection and data description are as follows:

U. S. monetary policy variables: (1) interest rate variable (IR). In the previous literature, the federal fund rate was selected as the proxy variable of the U.S. monetary policy interest rate policy. Since the federal fund rate was at the zero 
lower bound during the unconventional monetary policy period, it could not really reflect the change in the interest rate. Therefore, this paper selects the shadow short rate constructed by Krippner [23] as the proxy variable of interest rate in the period of the zero lower bound. After FOMC announced the interest rate hike in December 2015, the federal fund rate is selected as the proxy variable of the short-term interest rate. (2) Fed balance sheet variable (Fed asset). We select the asset size of the Federal Reserve balance sheet as the proxy variable and add the original weekly data to monthly data.

BRICS macroeconomic variables: (1) gross domestic product (GDP). We select the constant-price GDP of each country as an output proxy variable. For quarterly GDP data, this paper uses the quadratic-match average method to convert quarterly data into monthly data. (2) Inflation rate (CPI). We select the year-on-year change rate of the consumer price index as a proxy variable of inflation rate. (3) Balance of trade (BOT). We select the trade balance measured by the local currency of each country as the proxy variable and adjust it to the real value by CPI. (4) Exchange rate (REER). We select the real effective exchange rate index based on 2010 as the proxy variable of the exchange rate. The following Table 1 describes the variables used in our study.

Shadow short rate data are obtained from the Reserve Bank of New Zealand (the measure can be found at https:// www.rbnz.govt.nz/research-and-publications/researchprogramme/additional-research/measures-of-the-stanceof-united-states-monetary-policy). Federal Reserve balance sheet data are obtained from the Fed's official website (the data can be found at https://www.federalreserve.gov/ releases/h41/). BRICS macroeconomic variables data are obtained from the Wind Economic Database. All data are seasonally adjusted to remove seasonal factors. The software used in this paper are Eviews 10 and Stata 16.

\section{Empirical Results and Analysis}

Before estimating the PVAR model, it is necessary to test the stability of the variables and select the optimal lag order of the model.

4.1. Stationary Test. Stationarity is one of the key assumptions in time-series analysis. To avoid pseudoregression, we test the stationarity of all variables before PVAR analysis. As there are panel data and time series data in variables, we use three panel unit root tests for panel data and ADF unit root test for time-series data. The test results of panel unit root and time-series unit root are reported in Tables 2 and 3, respectively.

The results in Tables 2 and 3 show that the level values of GDP, CPI, BOT, REER, IR, and Fed asset cannot reject the null hypothesis at the $1 \%$ significance level; that is, the original series of each variable is nonstationary, but the firstorder difference values significantly reject the null hypothesis at the $1 \%$ significance level. In other words, variables are stationary after the first-order difference. Therefore, we can set the PVAR model for empirical analysis, and there is no pseudoregression problem.
4.2. Selection of Optimal Lag Order. Before using the PVAR model for further analysis, we need to select the optimal lag order of the PVAR model. Too large lag order may lead to the loss of a degree of freedom, increase variance decomposition error, and decrease estimation precision of impulse response function, while too small lag order may lead to autocorrelation error. In this paper, an optimal lag order is selected according to AIC, BIC, and HQIC information criteria. The test results are shown in Table 4. We find that AIC and HQIC have both chosen a model with eight lags, whereas BIC has selected a model with five lags. Based on various information criteria, the optimal lag order of the PVAR model is selected as eight.

4.3. Impulse Response Function Analysis. The impulse response function reflects the effect of one standard deviation shock of the disturbance term on each variable in the model. In this paper, the impulse response function of the Fed's interest rate hike and balance sheet reduction on BRICS output, inflation rate, trade balance, and the real effective exchange rate is obtained by Monte Carlo simulations. The U.S. monetary policy shock is set as one standard deviation interest rate hike and Fed asset expansion. The response function is shown for a horizon of 12 months.

\subsubsection{The Impact of U.S. Monetary Policy on GDP in BRICS} Countries. The impulse responses of BRICS output to the U.S. monetary policy shock are shown in Figure 1. The left panel of Figure 1 shows that given one standard deviation shock to the U.S. interest rate, output decreases significantly in response to a positive interest rate shock and then gradually shows a downward trend. The right panel of Figure 1 shows that given one standard deviation shock to Fed asset, output rises significantly in response to a positive Fed asset shock, reaching the maximum value after six months, and then gradually declines over time. This indicates that an increase in the U.S. interest rate and a decrease in Fed asset will lead to the reduction of aggregate output in BRICS countries. The possible reason is that the Fed's interest rate hike will increase American household savings while reducing their consumption, leading to a decline in the demand for foreign products, which would further worsen the BRICS 'trade balances and lower output. The Fed's reduction balance sheet will raise the bond risk premium and long-term yields, which will, on the one hand, lead to capital inflows to the United States and lower BRICS output through capital flow channels; on the other hand, it will cause investors to rebalance their portfolios, thus affecting the real economic activity of the BRICS countries by influencing the prices of various financial assets held abroad.

\subsubsection{The Impact of U.S. Monetary Policy on CPI in BRICS} Countries. The impulse responses of the BRICS inflation rate to the U.S. monetary policy shock are shown in Figure 2. The left panel of Figure 2 shows that given one standard deviation shock to the U.S. interest rate, the inflation rate decreases significantly in response to a positive interest rate 
TABLE 1: Description of the variables.

\begin{tabular}{lcc}
\hline Variable & Abbreviation & Measure \\
\hline Interest rate & IR & The federal fund rate and the shadow short rate constructed by Krippner \\
Fed balance sheet & Fed asset & The asset size of the Federal Reserve balance sheet \\
Gross domestic product & GDP & The constant-price GDP of each country \\
Inflation rate & CPI & The year-on-year change rate of consumer price index \\
Balance of trade & BOT & The trade balance measured by the local currency of each country \\
\hline
\end{tabular}

TABLE 2: The results of panel unit root tests.

\begin{tabular}{lcccccc}
\hline \multirow{2}{*}{ Variables } & \multicolumn{2}{c}{ LLC } & \multicolumn{2}{c}{ IPS } & \multicolumn{2}{c}{ FADF } \\
& Level & First difference & Level & First difference & Level & First difference \\
\hline GDP & -0.2702 & $-6.34768^{* * *}$ & -0.97608 & $101.218^{* * *}$ & 32.2759 & $210.074^{* * *}$ \\
CPI & 0.6015 & $-15.6830^{* * *}$ & -0.0766 & $-16.2748^{* * *}$ & 10.2445 & $211.1650^{* * *}$ \\
BOT & 0.05766 & $-34.5993^{* * *}$ & -2.13395 & $-34.0564^{* * *}$ & 19.8689 & $372.473^{* * *}$ \\
REER & -1.77743 & $-19.2512^{* * *}$ & -1.3072 & $-15.4446^{* * *}$ & 13.4360 & $181.9050^{* * *}$ \\
\hline
\end{tabular}

${ }^{* * *}$ Rejection of the null hypothesis at the $1 \%$ significance levels.

TABLe 3: The results of ADF test.

\begin{tabular}{lccccc}
\hline Variables & ADF statistics & $P$ value & Variables & ADF statistics & $P$ value \\
\hline IR & -2.3132 & 0.4231 & $\Delta \mathrm{IR}$ & -7.5018 & $P \leq 0.001$ \\
Fed asset & -2.5748 & 0.1013 & $\Delta$ Fed asset & -0.6121 & $P \leq 0.001$ \\
\hline
\end{tabular}

$\Delta$ First-order difference.

TABLe 4: Optimal lag order.

\begin{tabular}{lccc}
\hline Lag order & AIC & BIC & HQIC \\
\hline 4 & 3.42245 & 4.81519 & 3.96737 \\
5 & 3.11069 & $4.80372^{*}$ & 3.77337 \\
6 & 3.03239 & 5.0301 & 5.11562 \\
7 & 1.58658 & 2.4587 & 3.81465 \\
8 & $2.60968^{*}$ & 5.23035 & $3.63673^{*}$ \\
9 & 2.72469 & 5.98722 & 4.00436 \\
\hline
\end{tabular}

* Optimal lag order obtained according to the corresponding information criterion.

shock and then gradually shows a downward trend. The right panel of Figure 2 shows that given one standard deviation shock to Fed assets, inflation rate rises significantly in response to a positive Fed asset shock at the beginning, reaching the maximum value after seven months, and then gradually declines over time. This indicates that both higher interest rates and a shrinking of the Fed's balance sheet will decrease inflation in BRICS countries. This can be explained from two perspectives. On the one hand, tighter monetary policy in the United States will raise its short-term interest rates and longterm bond yields. The reduction of the spread between the United States and the BRICS will lead to capital inflow in the United States and reduce the inflation rate in BRICS countries. On the other hand, tighter U.S. monetary policy will reduce global liquidity, causing commodity prices to fall and bringing imported deflation to the BRICS countries.

\subsubsection{The Impact of U.S. Monetary Policy on BOT in BRICS} Countries. The impulse responses of BRICS trade balance to a U.S. monetary policy shock are shown in Figure 3. The left panel of Figure 3 shows that given one standard deviation shock to the U.S. interest rate, trade balance decreases significantly in response to a positive interest rate shock, but the impact has been in a state of fluctuation and then gradually increases to zero. The right panel of Figure 3 shows that the expansion of the Fed balance sheet has a positive impact on the BRICS trade balance and then gradually shows an upward trend. This indicates that both higher interest rates and a shrinking of the Fed's balance sheet will worsen trade balance in BRICS countries. The possible reason is that the tighter U.S. monetary policy will somewhat weaken U.S. domestic consumption and reduce demand for BRICS commodities, but as the U.S. dollar continues to appreciate and the BRICS currencies depreciate, the BRICS' export competitiveness will be enhanced, which ultimately led to a shrinking trade balance.

\subsubsection{The Impact of U.S. Monetary Policy on REER in BRICS} Countries. The impulse responses of the BRICS exchange rate to the U.S. monetary policy shock are shown in Figure 4. The left panel of Figure 4 shows that given one standard deviation shock to U.S. interest rate, the real effective exchange rate of BRICS countries decreases significantly, except for a brief rise in the fourth period, reaching the minimum value after eight months, and then gradually converges to zero. The right panel of Figure 4 shows that given one standard deviation shock to Fed asset, a real effective exchange rate rises significantly in response to a positive Fed asset shock at the beginning, reaching the maximum value after five months then gradually declining over time. This indicates that both higher interest rates and a shrinking of the Fed's balance sheet will lead to the appreciation of the dollar and the depreciation of BRICS currencies. This can be explained from two perspectives. On 

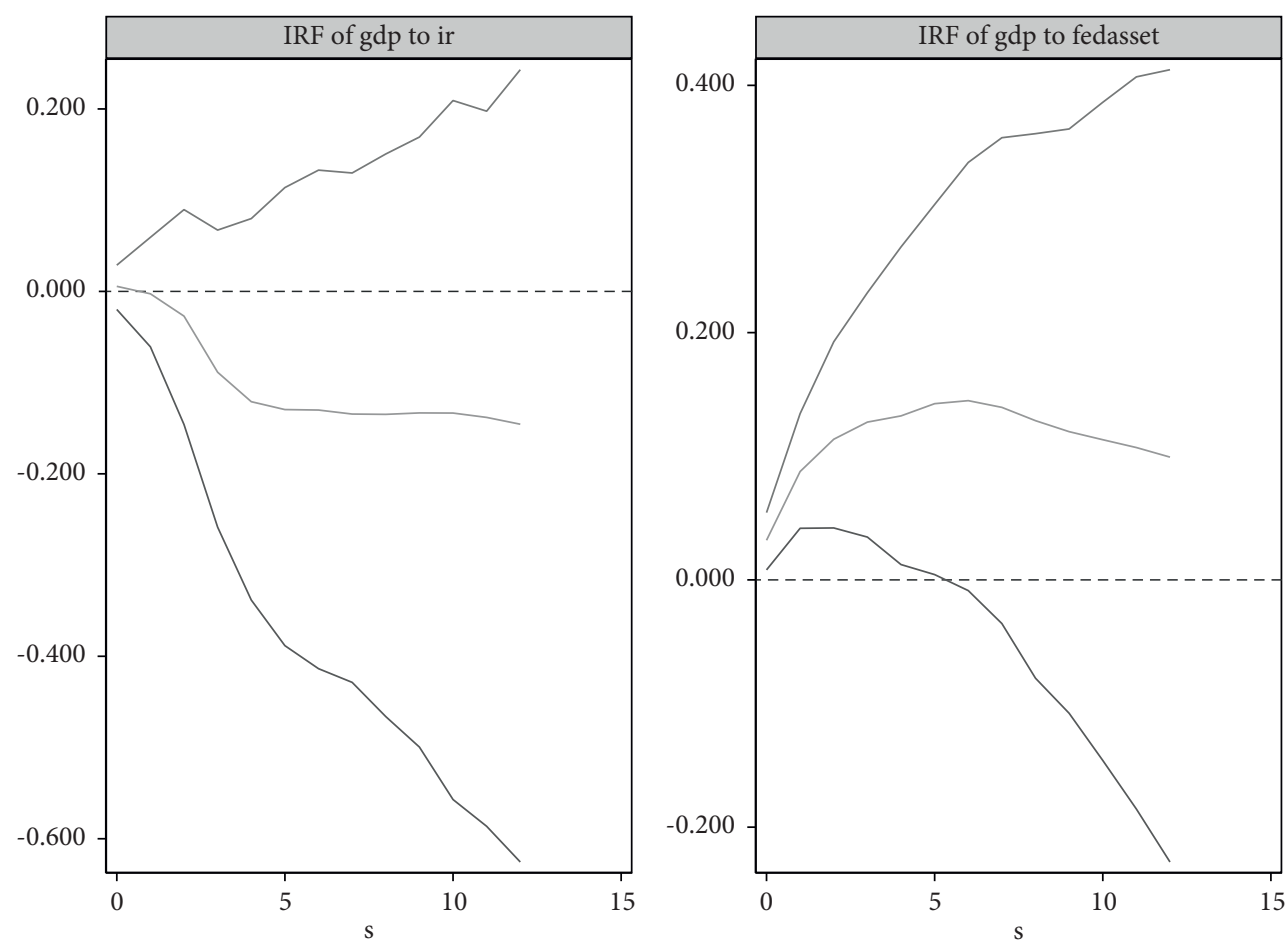

FIGURE 1: Impulse responses of GDP to U.S. monetary policy shock in BRICS countries.
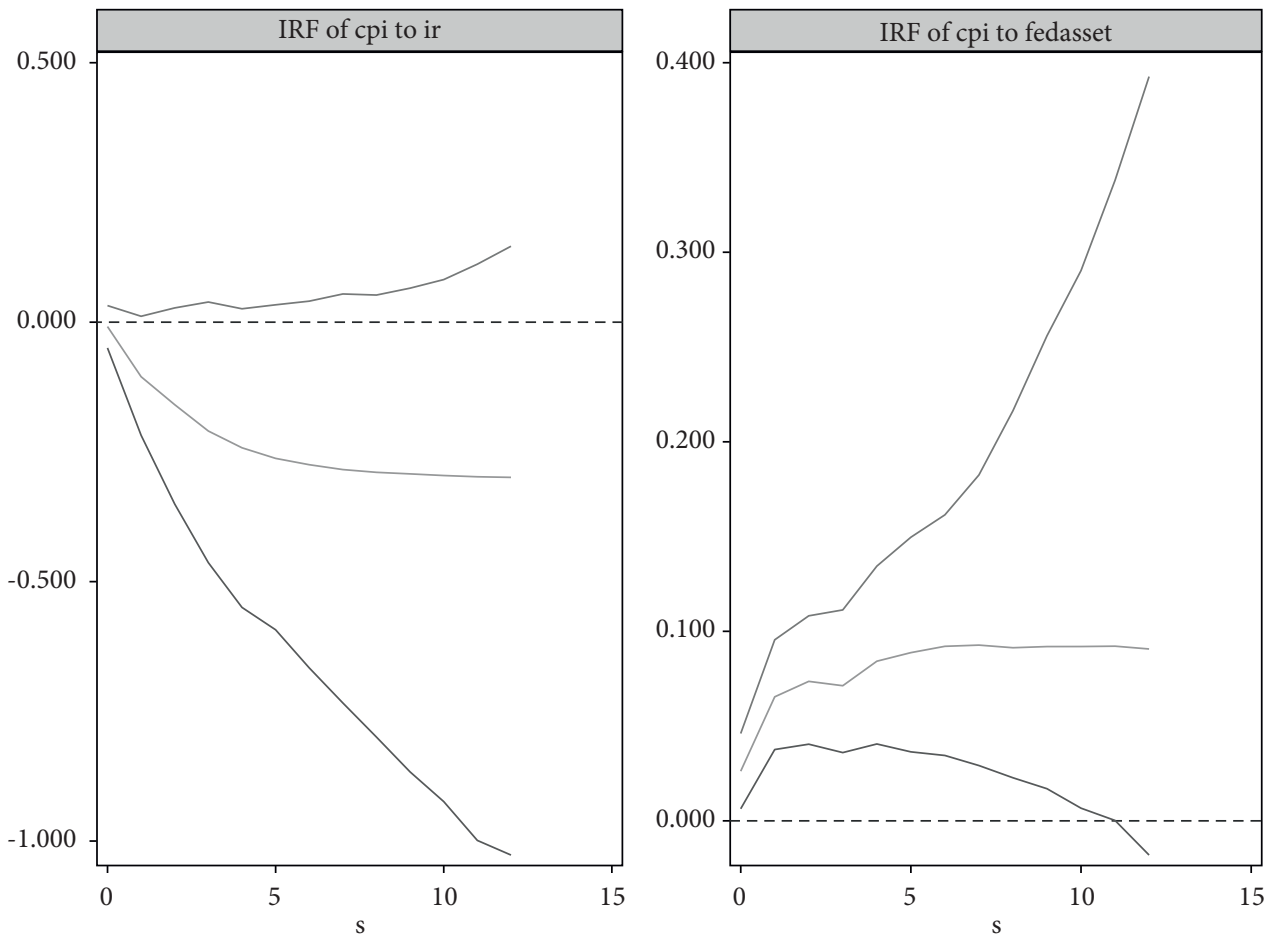

FIGURE 2: Impulse responses of CPI to U.S. monetary policy shock in BRICS countries.

the one hand, according to the uncovered interest rate parity theory, the exchange rate is determined by the difference in interest rates between two countries, and the spread will cause the cross-border flow of funds in the international market. Therefore, the Fed's interest rate hike will trigger the continuous inflow of international speculative funds into the
United States, which increases the U.S. dollar appreciation pressure and leads to the depreciation of BRICS currencies. On the other hand, shrinking the Fed's balance sheet will withdraw large amounts of liquidity directly from the market, increasing the value of the U.S. dollar relative to the BRICS currencies. 

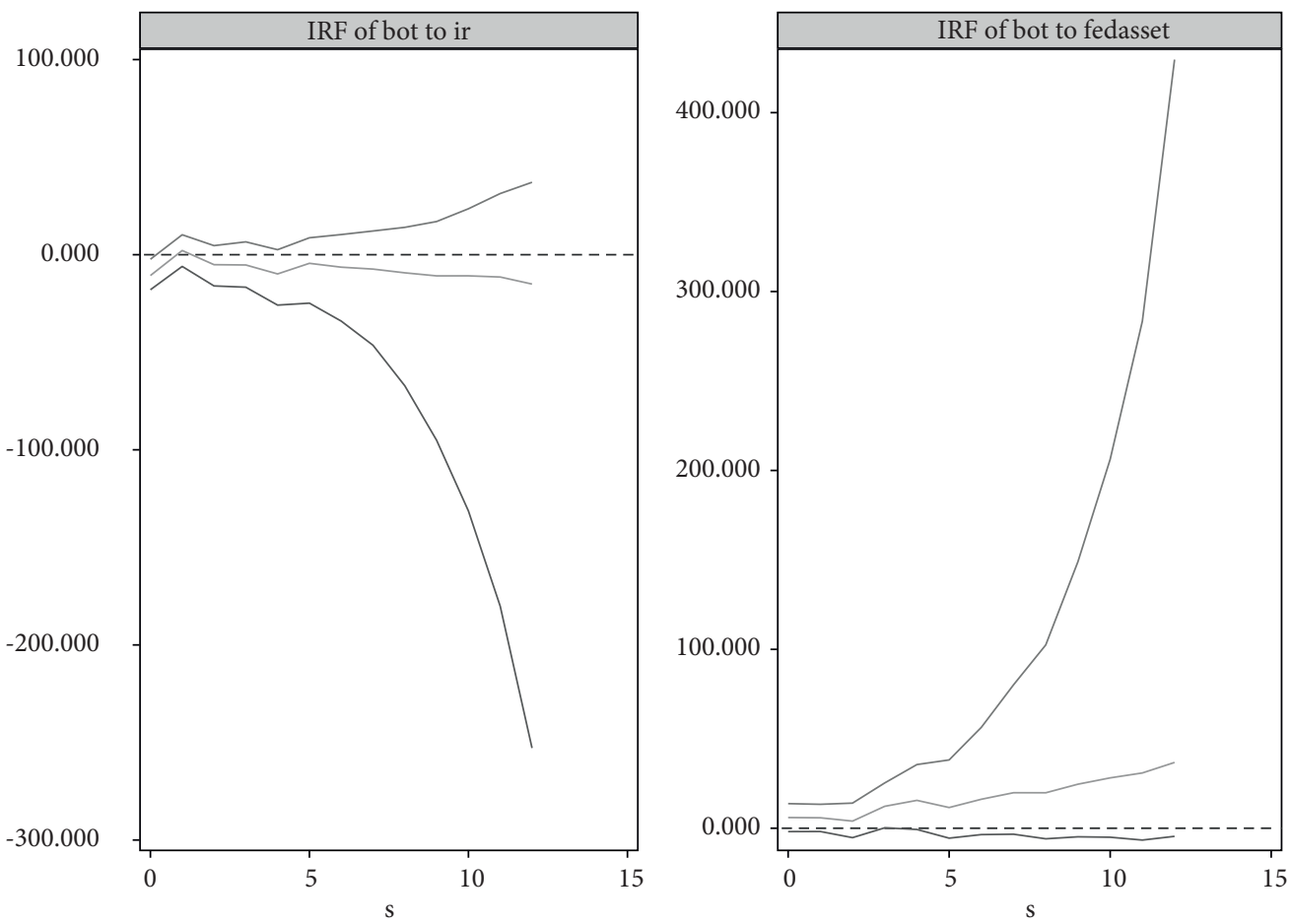

FIgURE 3: Impulse responses of BOT to U.S. monetary policy shock in BRICS countries.
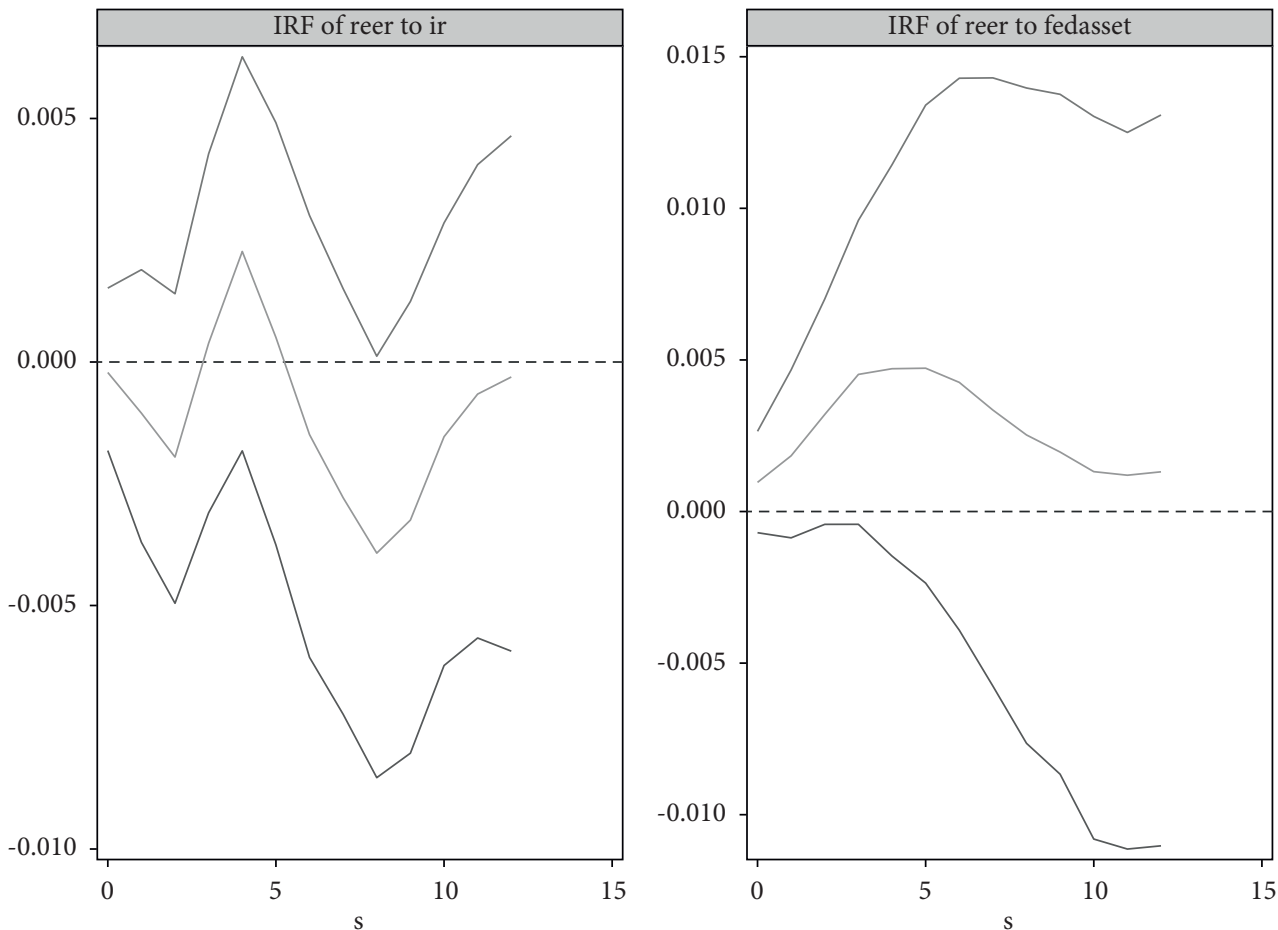

FIGURE 4: Impulse responses of REER to U.S. monetary policy shock in BRICS countries.

4.4. Variance Decomposition. Through variance decomposition, we can test the contribution and relative importance of monetary policy shocks to other variables in the model. Tables 5 and 6 present the variance decomposition results of the U.S. interest rate shock and the Federal Reserve balance sheet shock on the BRICS macroeconomic variables, respectively.
Table 5 reveals that the contribution of U.S. interest rate shocks to GDP increases in the first 15 months, reaching 9.5\% at the peak, and then decreases after 15 months. The contribution of interest rate shocks to CPI, BOT, and REER has been increasing, reaching the maximum value of $5.3 \%$, $22.3 \%$, and $5.5 \%$, respectively, in the 30th month; this 
TABLE 5: The variance decomposition to interest rate shock.

\begin{tabular}{lcccc}
\hline \multicolumn{5}{c}{ Interest rate shock } \\
Horizon & GDP & CPI & BOT & REER \\
\hline 5 & 0.015 & 0.001 & 0.011 & 0.009 \\
10 & 0.054 & 0.012 & 0.013 & 0.013 \\
15 & 0.095 & 0.034 & 0.028 & 0.013 \\
20 & 0.091 & 0.048 & 0.094 & 0.010 \\
25 & 0.075 & 0.052 & 0.168 & 0.025 \\
30 & 0.059 & 0.053 & 0.223 & 0.055 \\
\hline
\end{tabular}

The table reports the $k$-month-ahead forecast errors that interest rate shock account for. The forecast horizon $k$ we report takes the values $5,10,15,20$, 25 , and 30 .

TABle 6: The variance decomposition to fed asset shock.

\begin{tabular}{lcccc}
\hline \multicolumn{4}{c}{ Fed asset shock } \\
Horizon & GDP & CPI & BOT & REER \\
\hline 5 & 0.014 & 0.019 & 0.006 & 0.003 \\
10 & 0.016 & 0.020 & 0.032 & 0.004 \\
15 & 0.017 & 0.022 & 0.043 & 0.012 \\
20 & 0.023 & 0.022 & 0.054 & 0.020 \\
25 & 0.033 & 0.030 & 0.074 & 0.026 \\
30 & 0.037 & 0.038 & 0.111 & 0.036 \\
\hline
\end{tabular}

The table reports the $k$-month-ahead forecast errors that fed asset shock account for. The forecast horizon $k$ we report takes the values $5,10,15,20$, 25 and 30.

indicates that the U.S. interest rate has a sustained impact on output, inflation rate, and exchange rate in BRICS countries, among which the U.S. interest rate shock make the greatest contribution to the trade balance. Table 6 reveals that the contribution of fed balance sheet shock to GDP, CPI, BOT, and REER has been increasing, reaching the maximum value of $3.7 \%, 3.8 \%, 11.1 \%$, and $3.6 \%$, respectively, in the 30th month. This indicates that the Fed balance sheet shock also has a sustained impact on various economic variables in BRICS countries. Finally, a comparative analysis of Tables 5 and 6 reveals that the U.S. interest rate shocks explain the BRICS' economic variables better than the balance sheet shocks.

\section{Conclusions and Policy Implications}

Using the PVAR model, this paper empirically analyzes the spillover effects of the Fed's interest rate hike and balance sheet reduction on BRICS output, inflation rate, trade balance, and exchange rate. The main conclusions are as follows: first, the U.S. monetary policy has a significant spillover effect on the BRICS countries. The Fed's interest rate hike and shrinking its balance sheet will lead to the decline of output, inflation rate, trade balance deterioration, and currency depreciation in BRICS countries. Second, much more of output, inflation rate, trade balance, and exchange rate in BRICS countries can be explained by the U.S. interest rate shock, while the balance sheet shock explains a smaller proportion.

Based on the conclusions of this paper, BRICS countries can take different measures to mitigate the adverse effects of the U.S. monetary policy: first, BRICS countries should strengthen the supervision of international capital flow. In the context of the adjustment of the U.S. monetary policy, the change of interest rate spread will cause a fundamental change in international capital flow, and establish and improve the monitoring system of short-term international capital inflow and outflow, which can prevent the potential risks brought by international capital flow to the macroeconomy of each country. Second, BRICS countries should pay close attention to commodity prices, enhance their bargaining power over commodities in the international market, and prevent drastic fluctuations in domestic prices caused by commodity price fluctuations. Third, BRICS countries should appropriately use foreign exchange reserves to regulate exchange rates and improve their macroeconomic fundamentals such as economic growth so that the volatility of the exchange rate is reduced.

\section{Data Availability}

All the data are included within the article. Further data can be requested from the corresponding author upon reasonable request.

\section{Conflicts of Interest}

The authors declare that they have no conflicts of interest.

\section{Acknowledgments}

This study was supported by the National Social Science Fund of China (Macroeconomic Impact of Liquidity Structure Imbalance and Monetary Policy Choice in China, Grant no. 14BJY187).

\section{References}

[1] S. Papadamou, C. Siriopoulos, and N. A. Kyriazis, "A survey of empirical findings on unconventional central bank policies," Journal of Economics Studies, vol. 47, no. 7, pp. 1533-1577, 2020.

[2] Y. Sun and Q. Zhang, "Analysis on time varying, fed's interest rate hike and China's output-based on TVP-VAR model," Studies of International Finance, vol. 348, pp. 26-36, 2016.

[3] R. Banerjee, M. B. Devereux, and G. Lombardo, "Self-oriented monetary policy, global financial markets and excess volatility of international capital flows," Journal of International Money and Finance, vol. 68, pp. 275-297, 2016.

[4] G. Georgiadis, "Determinants of global spillovers from US monetary policy," Journal of International Money and Finance, vol. 67, pp. 41-61, 2016.

[5] A. M. Checo, S. Pradel, and F. A. Ramírez, The effects of USA monetary policy on Central America and the Dominican republic, pp. 189-222, Investigación Conjunta-Joint Research, in: Ángel Estrada García \& Alberto Ortiz Bolaños (ed.), International Spillovers of Monetary Policy, Centro de Estudios Monetarios Latinoamericanos, CEMLA, Buenos Aires, Argentina, 1st edition, 2017.

[6] M. Iacoviello and G. Navarro, "Foreign effects of higher U.S. interest rates," Journal of International Money and Finance, vol. 95, pp. 232-250, 2019.

[7] J. Aizenman, M. D. Chinn, and H. Ito, "Balance sheet effects on monetary and financial spillovers: the East Asian crisis plus 
20," Journal of International Money and Finance, vol. 74, pp. 258-282, 2017.

[8] X. Tan, W. Yin, and W. Dai, "The impact of fed tapering on emerging markets economies," Studies of International Finance, vol. 351, pp. 18-32, 2016.

[9] H. A. Almahadin, "Spillover effects of US monetary policy on banking development: evidence from the Asian region," Global Business Review, 2019.

[10] N. K. Anaraki, "Fed's interest rate policy and capital reversals: empirical evidence from BRICs," Journal of Finance and Accountancy, vol. 27, 2020.

[11] M. Hanisch, "US monetary policy and the euro area," Journal of Banking \& Finance, vol. 100, pp. 77-96, 2019.

[12] R. Zhou, "The impact of fed's increasing of interest rate on world economy," Asia-pacific Economic Review, vol. 6, pp. 22-29, 2016.

[13] Y. Bai, Z. Wang, and Y. Chen, "Research on the impact of the exit of unconventional monetary policy in the U.S. On the real output of China-international analysis based on signal channel," Studies of International Finance, vol. 340, pp. 21-30, 2015.

[14] X. Jiang, B. Wang, and T. He, "Research on the impact of the Fed's balance sheet reduction based on an international perspective," New Finance, vol. 11, pp. 18-22, 2017.

[15] A. Apostolou and J. Beirne, "Volatility spillovers of unconventional monetary policy to emerging market economies," Economic Modelling, vol. 79, pp. 118-129, 2019.

[16] L. Brainard, Cross-Border Spillovers of Balance Sheet Normalization: A Speech at the National Bureau of Economic Research's Monetary Economics Summer Institute, Board of Governors of the Federal Reserve System (US), New York, NY, USA, 2017.

[17] M. Singh, H. Wang, and G. Gelos, "Central bank balance sheet policies and spillovers to emerging markets," IMF Working Papers 2017, vol. 172, 2017.

[18] X. Song and D. Ye, "The Fed's method of shrinking balance sheet and its impact," China Financialyst, vol. 9, pp. 84-86, 2017.

[19] W. Xiao and X. Lan, "The spillover effect of federal reserve monetary policy normalization on China's economy," World Economy Studies, vol. 12, pp. 38-49, 2017.

[20] D. Holtz-Eakin, W. Newey, and H. S. Rosen, "Estimating vector autoregressions with panel data," Econometrica, vol. 56, no. 6, pp. 1371-1395, 1988.

[21] M. Arellano and S. Bond, "Some tests of specification for panel data: Monte Carlo evidence and an application to employment equations," The Review of Economic Studies, vol. 58, no. 2, pp. 277-297, 1991.

[22] M. Arellano and O. Bover, "Another look at the instrumental variable estimation of error-components models," Journal of Econometrics, vol. 68, no. 1, pp. 29-51, 1995.

[23] L. Krippner, "Measuring the stance of monetary policy in zero lower bound environments," Economics Letters, vol. 118, no. 1, pp. 135-138, 2013. 